\title{
Persepsi Pasien terhadap Bauran Pemasaran Rumah Sakit dan Pilihan Rumah Sakit
}

\section{Patient perception of Hospital Marketing Mix and Choice of Hospital}

\author{
Sri Retnaningtyas ${ }^{1}$, Endah Woro $U^{1}$, Mafrurrochim Hasyim ${ }^{2}$ \\ ${ }^{1}$ Program Studi Magister Manajemen Rumah Sakit Fakultas Kedokteran Universitas Brawijaya Malang \\ ${ }^{2}$ Rumah Sakit Syuhada' Haji Blitar
}

\begin{abstract}
ABSTRAK
Penelitian ini bertujuan untuk mengetahui gambaran persepsi pasien terhadap bauran pemasaran menurut pilihan utama pasien rawat inap. Jenis penelitian deskriptif dengan sampel 36 responden yang dipilih secara accidental sampling. Penelitian dilakukan di unit rawat inap Kelas I, Kelas II, Kelas III dan Kelas VIP di RS Syuhada' Haji selama 3 hari. Variabel yang diukur meliputi bauran pemasaran yaitu: produk, lokasi, karyawan, proses, tarif, promosi, dan lingkungan fisik serta penialaian umum dan pilihan utama pelayanan. Hasil menunjukkan persepsi positif pada bauran produk, proses, tarif, dan keahlian namun pada aspek lokasi, promosi, serta penampilan fisik dianggap kurang. Responden juga sebagian besar menyatakan rumah sakit ini sebagai pilihan utama dan menganggap pelayanan yang diberikan adalah terbaik. Tabulasi silang menunjukkan pada responden yang menjadikan rumah sakit ini sebagai pilihan utama cenderung memberikan penilaian yang lebih tinggi pada semua aspek bauran pemasaran dibandingkan yang menyatakan bukan sebagai pilihan utama. Temuan ini mengindikasikan bahwa bauran pemasaran dapat menjadi faktor yang menjadi pertimbangan pasien ketika memilih rumah sakit.
\end{abstract}

Kata Kunci: Bauran pemasaran, pilihan rumah sakit, persepsi pasien

\begin{abstract}
This study aims to obtain patient's perception on marketing mix according to main selection of inpatients. This is a descriptive research with 36 respondents who were selected using accidental sampling. The research was conducted at inpatient units Class I, Class II, Class III and Class VIP in Syuhada' Haji hospital for 3 days. Variables measured were including marketing mix, namely products, location, employees, processes, tariffs, promotion, and physical environments as well as public judgment and main choice of services. The results show a positive perception on the mixes of products, processes, tariffs, and expertise while the aspects of the location, promotion, and physical appearance were considered less. Respondents were also mostly expressed this hospital as the primary choice and considered the services provided were best. Cross tabulation showed the respondents who decided this hospital as the primary choice tended to give higher ratings on all aspects of the marketing mix than those who expressed not as a primary choice. These findings indicate that the marketing mix can be patient's consideration factors when choosing a hospital.
\end{abstract}

Keywords: Choice of hospital, marketing mix, patient's perception

Korespondensi: Sri Retnaningtyas. Program Studi Magister Manajemen Rumah Sakit Fakultas Kedokteran Universitas Brawijaya Malang, Jl. Veteran Malang Jawa Timur Tel. (0341) 568989 Email: retnaningtyas.sri@gmail.com 


\section{PENDAHULUAN}

Pemanfaatan rawat inap di rumah sakit dapat digambarkan oleh data BOR rumah sakit. BOR (Bed Occupancy Rate ) merupakan salah satu indikator kinerja rumah sakit yang menyatakan prosentase pemakaian tempat tidur pada satu satuan waktu tertentu. Indikator ini memberikan gambaran tinggi rendahnya tingkat pemanfaatan tempat tidur di rumah sakit. Nilai BOR yang ideal adalah 60-85\%. BOR yang masih rendah mengindikasikan bahwa keputusan pasien untuk memanfaatkan rawat inap di rumah sakit masih rendah. Data BOR yang rendah merupakan salah satu dasar manajemen untuk melakukan upaya perbaikan efisiensi tempat tidur di rumah sakit.

Berdasarkan Laporan Tahunan dan Profil RS Syuhada' Haji memiliki nilai BOR yang fluktuatif. Nilai rata-rata BOR selama tahun 2011 sampai 2013 adalah 46,24\%. Pada tahun 2012 BOR mengalami penurunan sejumlah 3,7\% dibandingkan tahun 2011. Sebaliknya pada tahun 2013 BOR mengalami meningkat sebesar 6,75 dibandingkan tahun 2011 dan 10,45 \% dibandingkan BOR tahun 2012 (Tabel 1). Meskipun cenderung meningkat pada tahun terakhir (2013), bila dibandingkan dengan standar BOR RS Syuhada' Haji pada tahun 2011 sampai tahun 2013 masih rendah atau belum sesuai standar yaitu 60-85\%. Data tersebut menunjukkan tempat tidur yang disediakan rumah sakit masih belum banyak digunakan. Hal ini menggambarkan bahwa keputusan pasien untuk pemanfaatan rawat inap di RS Syuhada' Haji masih rendah. Pemanfaatan rawat inap yang belum optimal oleh masyarakat mengakibatkan utilisasi di rawat inap belum sesuai dengan harapan manajemen yang berdampak pada pendapatan unit rawat inap.

Tabel 1. Data BOR RS Syuhada' Haji 2011-2013

\begin{tabular}{cc}
\hline Tahun & Nilai BOR \\
\hline 2011 & $45,22 \%$ \\
2012 & $41,52 \%$ \\
2013 & $51,97 \%$ \\
\hline
\end{tabular}

Sumber: Laporan Tahunan RSSH 2014

Terdapat beberapa strategi untuk meningkatkan pemanfaatan rumah sakit. Penelitian Susanto pada ruang rawat inap yang memiliki BOR rendah, menyebutkan bahwa untuk meningkatkan BOR perlu dilakukan analisis faktor-faktor yang mempengaruhi BOR. Faktor-faktor tersebut adalah faktor input, faktor proses pelayanan, dan faktor kondisi pasien yang menjadi konsumen dari rumah sakit. Variabel input meliputi sarana umum, sarana medis, sarana penunjang medis, tarif, ketersediaan pelayanan, dan tenaga atau karyawan. Disamping input, variabel proses pelayanan meliputi sikap dokter dan sikapa perawat dalam memberikan pelayanan kepada pasien, serta ada tidaknya kesinambungan pelayanan di rumah sakit(1).

Disamping faktor-faktor tersebut, penggunaan pelayanan rumah sakit juga dipengaruhi pilihan atau keputusan pasien. Penelitian Andayanie menyebutkan bahwa pasien memutuskan untuk memanfaatkan rawat inap secara individu dipengaruhi oleh beberapa aspek, yaitu persepsi, cara memperoleh informasi, sikap, demografi, kepribadian, dan gaya hidup pasie. Nurlia menyebutkan bahwa informasi yang akurat dapat mempengaruhi pengetahuan pasien yang berdampak pada persepsi, keyakinan dan motivasi pasien mengenai pelayanan rumah sakit yang akhirnya mempengaruhi keputusan pasien untuk memanfaatkan pelayanan rawat inap di rumah sakit(2).

Faktor informasi yang mempengaruhi keputusan pasien dalam memanfaatkan rumah sakit dipengaruhi oleh strategi pemasaran rumah sakit. Dalam mengelola strategi pemasaran sebagai upaya untuk meningkatkan kunjungan di rawat inap perlu dilakukan kajian faktor determinan pada variable bauran pemasaran (marketing mix). Semakin baik faktor determinan bauran pemasaran maka semakin tinggi pula kunjungan pasien terhadap pemanfaatan layanan yang ditawarkan (3). Gambaran kinerja bauran pemasaran di suatu rumah sakit akan menjadi dasar dalam menetapkan strategi pemasaran yang tepat. Penelitian ini dilakukan untuk mengekplorasi persepsi pasien tentang bauran pemasaran di RS Syuhada' Haji, serta persepsi pasien terhadap pilihan pelayanan rawat inap.

\section{METODE}

Penelitian dilakukan dengan survei untuk menggali persepsi pasien pada bauran pemasaran di rumah sakit serta pilihan utama pasien terhadap pelayanan di rumah sakit. Variabel bauran diukur menggunakan kuesioner dengan empat skala Likert diadopsi dari penelitian Kafa, 2013. Pilihan utama pasien mengukur apakah pilihan saat ini di RS Syuhada' Haji merupakan pilihan utama atau tidak serta bagaimana penilaian mereka terhadap pelayanan di rumah sakit.

Populasi penelitian meliputi pasien dan keluarganya yang ada di rawat inap RS Syuhada' Haji baik yang datang dengan rujukan maupun datang langsung. Hal ini sesuai dengan penelitian oleh Nurlinda dan Sampeluna yang menyebutkan pentingnya peran keluarda dalam pemanfaatan atau pemilihan provider pelayanan kesehatan $(4,5)$. Penelitian ini mengambil sampel yaitu pasien dan keluarga pasien yang pada saat dilakukan pengumpulan data terdaftar sebagai pasien yang sedang rawat inap di RS Syuhada' Haji. Responden adalah pasien atau keluarga pasien dewasa, usia diatas 18 tahun, dapat berkomunikasi dengan baik, bersedia mengisi kuesioner, dan bukan pegawai RS Syuhada' Haji atau keluarganya. Dasar penentuan sesuai dengan rumus adalah Isaac dan Michael dalam Sugiyono dengan tingkat kesalahan 10\%. Sampel diambil berdasarkan jumlah pasien rawat inap di RS Syuhada' Haji rata-rata selama 3 hari sejumlah 36. Kuesioner disebarkan selama 3 hari pada unit rawat inap kelas 1, kelas 2, kelas 3 dan kelas VIP yang sedang melakukan rawat inap di RS Syuhada' Haji.

\section{HASIL}

\section{Gambaran Karakteristik Pengguna Layanan Rumah Sakit}

Responden yang menggambarkan pengguna layanan rumah sakit sebagian besar wanita $(61 \%)$ dan berusia diatas 50 tahun (36\%). Responden terbanyak berasal dari Kabupaten Blitar yaitu sebanyak 94\%, rata-rata adalah petani, wiraswasta dan ibu rumah tangga yaitu masingmasing $31 \%$. Penghasilan rata-rata responden kurang dari Rp. 3.000 .000 per bulan yaitu $92 \%$ dan berobat atas biaya sendiri sebanyak $64 \%$ dan $13 \%$ dibiayai oleh keluarga. Sebagian besar responden pasien baru yang masih 
pertama kali melakukan kunjungan rawat inap di Rs Syuhada' Haji (58\%) dengan perujuk utama adalah keluarga (97\%). Secara keseluruhan data menunjukkan bahwa pengguna layanan rumah sakit mempunyai status ekonomi menengah kebawah dan mempunyai pilihan karena tidak menggunakan asuransi dengan sumber pertimbangan utama adalah keluarga dengan area pasar di Kabupaten Blitar.

Tabel 2. Karakteristik responden

\begin{tabular}{|c|c|c|c|}
\hline Kreteria & Keterangan & Frekuensi & Persentase \\
\hline \multirow[t]{2}{*}{ Jenis Kelamin } & a. Laki-laki & 14 & $39,0 \%$ \\
\hline & b. Wanita & 22 & $61,0 \%$ \\
\hline \multirow[t]{5}{*}{ Usia } & a. $18-20$ tahun & 3 & $8 \%$ \\
\hline & b. $23-30$ tahun & 6 & $17 \%$ \\
\hline & c. $31-40$ tahun & 9 & $25 \%$ \\
\hline & d. $41-50$ tahun & 5 & $14 \%$ \\
\hline & e. lebih 50 tahun & 13 & $36 \%$ \\
\hline \multirow[t]{2}{*}{ Asal Daerah } & a. Kabupten Blitar & 34 & $94 \%$ \\
\hline & b. Kota Blitar & 2 & $6 \%$ \\
\hline \multirow[t]{5}{*}{ Jenis pekerjaan } & a. Pegawai swasta & 2 & $6 \%$ \\
\hline & b. Wiraswasta & 11 & $31 \%$ \\
\hline & e. Petani & 11 & $31 \%$ \\
\hline & g. Ibu rumah tangga & 11 & $31 \%$ \\
\hline & h. lain-lain & 1 & $3 \%$ \\
\hline \multirow{3}{*}{$\begin{array}{l}\text { Penghasilan setiap } \\
\text { bulan }\end{array}$} & a. $<$ Rp.3.000.000 & 33 & $92 \%$ \\
\hline & b. Rp. 3.000 .000 & $\begin{array}{c}50 \\
3\end{array}$ & $8 \%$ \\
\hline & -Rp. 5.000 .000 & 3 & \\
\hline \multirow[t]{2}{*}{ Berobat atas biaya } & a. Biaya sendiri & 23 & $64 \%$ \\
\hline & b. Dibiayai keluarga & 13 & $36 \%$ \\
\hline \multirow[t]{2}{*}{ Perujuk Utama } & a. Saran Dokter & 1 & $3 \%$ \\
\hline & b. Saran Keluarga & 35 & $97 \%$ \\
\hline
\end{tabular}

Persepsi Responden terhadap Bauran Pemasaran Rumah Sakit

Secara keseluruhan hasil menunjukkan responden sebagian besar mempunyai persepsi positif (setuju) terhadap komponen dan item penilaian bauran pemasaran rumah sakit (Tabel 3). Meskipun demikian terdapat beberapa komponen yang memiliki rerata tinggi atau dinilai lebih baik dengan komponen bauran pemasaran lain yaitu aspek produk, proses, tarif, dan keahlian. Pada aspek lokasi, promosi, dan bukti fisik masih mendapatkan penilaian kurang dari pengguna. Bahkan pada bukti fisik aspek kebersihan lingkungan mendapatkan penilaian yang sangat rendah. Temuan ini mengindikasikan bahwa meskipun rumah sakit pada aspek inti pelayanan yaitu produk, proses, tarif, dan keahlian sudah dinilai bagus namun dari aspek penampilan yaitu kebersihan masih kurang juga promosi dan kemudahan akses atau aspek lokasi.

\section{PersepsiUmum dan Pilihan Utama Pelayanan}

Data menunjukkan bahwa sebagian besar responden menyatakan RSSH sebagai pilihan utama (72\%) meskipun masih terdapat (18\%) pasien yang tidak menganggap RSSH sebagai pilihan utama. Pilihan utama tersebut juga didukung fakta persepsi responden yang cenderung positif dan menganggap RSSH memberikan pelayanan yang terbaik, didukung keseuaian harga dan kualitas pelayanan serta petugas dan sarana yang dipandang baik pula (Tabel $4)$.

\section{Tabel 4. Gambaran persepsi umum dan pilihan utama pelayanan}

\begin{tabular}{lccc}
\hline \multicolumn{1}{c}{ Pilihan dan Penilaian } & Setuju & Tidak Setuju & Rerata Skor \\
\hline RSSH ini adalah pilihan utama & 26 & 10 & 2,83 \\
$\begin{array}{l}\text { RSSH memberikan pelayanan yang } \\
\text { terbaik }\end{array}$ & 35 & 1 & 3,19 \\
$\begin{array}{l}\text { RSSH memberikan penawaran harga } \\
\text { sesuai kualitas }\end{array}$ & 36 & 0 & 3,11 \\
$\begin{array}{l}\text { Pelayanan penunjang RSSH cukup } \\
\text { lengkap }\end{array}$ & 36 & 0 & 3,08 \\
$\begin{array}{l}\text { Semua tenaga medis RSSH selalu } \\
\text { ramah }\end{array}$ & 35 & 1 & 3,14 \\
\end{tabular}

Tabel 5 menunjukkan penilaian bauran pemasaran dihubungkan dengan apakah rumah sakit menjadi pilihan utama. Secara deskriptif data mengindikasikan meskipun hanya sedikit, pasien yang memilih rumah sakit tempat studi sebagai pilihan utama cenderung mempunyai penilaian yang sedikit lebih baik disemua aspek bauran pemasaran. Pada aspek keahlian kedua kelompok responden memberikan persepsi positif yang cenderung sama. Data ini mengindikasikan bahwa penilaian terhadap bauran pemasaran dapat menjadi faktor yang dipertimbangkan pasien dan keluarga ketika memilih rumah sakit.

Tabel 5. Persepsi bauran pemasaran menurut pilihan rumah sakit

\begin{tabular}{|c|c|c|}
\hline \multirow{2}{*}{$\begin{array}{c}\text { Bauran } \\
\text { Pemasaran }\end{array}$} & \multicolumn{2}{|l|}{ Rerata Skor } \\
\hline & $\begin{array}{l}\text { Pilihan } \\
\text { Utama }\end{array}$ & $\begin{array}{l}\text { Bukan } \\
\text { Pilihan }\end{array}$ \\
\hline Produk & 3,15 & 2,98 \\
\hline Lokasi & 2,91 & 2,68 \\
\hline Proses & 3,12 & 2,93 \\
\hline Tarif & 2,87 & 2,83 \\
\hline Promosi & 2,87 & 2,73 \\
\hline Keahlian & 3,15 & 3,12 \\
\hline Bukti Fisik & 3,08 & 2,80 \\
\hline
\end{tabular}

Tabel 3. Persepsi responden terhadap bauran pemasaran rumah sakit

\begin{tabular}{|c|c|c|c|c|c|c|}
\hline \multirow{3}{*}{$\begin{array}{l}\text { Bauran Pemasaran } \\
\text { Produk }\end{array}$} & \multirow{3}{*}{$\begin{aligned} \text { Indikator } \\
\text { RSSH memiliki dokter jaga } 24 \text { jam }\end{aligned}$} & \multicolumn{5}{|c|}{ Respon } \\
\hline & & \multicolumn{2}{|c|}{ Setuju (\%) } & \multicolumn{2}{|c|}{ Tidak Setuju (\%) } & \multirow{2}{*}{$\begin{array}{c}\text { Skor Rerata } \\
3,03\end{array}$} \\
\hline & & 31 & $(86,1)$ & 5 & 13,9 & \\
\hline & Dokter spesialis lengkap & 31 & 86,1 & 5 & 13,9 & 3,00 \\
\hline & Laborat dan radiologi lengkap & 35 & 97,2 & 1 & 2,8 & 3,19 \\
\hline & Terdapat pelayanan kamar operasi & 33 & 91,7 & 3 & 8,3 & 3,14 \\
\hline & Pelayanan Farmasi lengkap & 36 & 100 & 0 & 0 & 3,25 \\
\hline & Pelayanan gizi baik & 30 & 83,3 & 6 & 16,7 & 3,00 \\
\hline
\end{tabular}


Tabel 3. Persepsi responden terhadap bauran pemasaran rumah sakit (lanjutan)

\begin{tabular}{|c|c|c|c|c|c|c|}
\hline \multirow{3}{*}{$\begin{array}{l}\text { Bauran Pemasaran } \\
\text { Lokasi }\end{array}$} & \multirow{4}{*}{$\begin{array}{l}\text { Indikator } \\
\text { Mudah dicapai dengan kendaraan umum } \\
\text { Pilihan terdekat }\end{array}$} & \multicolumn{5}{|c|}{ Respon } \\
\hline & & \multicolumn{2}{|c|}{ Setuju (\%) } & \multicolumn{2}{|c|}{ Tidak Setuju (\%) } & \multirow{2}{*}{$\begin{array}{c}\text { Skor Rerata } \\
2,89\end{array}$} \\
\hline & & 27 & 75 & 9 & 25 & \\
\hline & & 22 & 61,1 & 14 & 38,9 & 2,61 \\
\hline & Tempat parkir luas & 30 & 83,3 & 6 & 16,7 & 2,92 \\
\hline & Lokasi strategis & 33 & 91,7 & 3 & 91,7 & 2,92 \\
\hline & Jumlah kamar cukup & 30 & 83,3 & 6 & 16,7 & 2,92 \\
\hline \multirow[t]{7}{*}{ Proses } & Perawat ruang rawat inap tanggap & 36 & 100 & 0 & 0 & 3,19 \\
\hline & Petugas rawat inap ramah & 36 & 100 & 0 & 0 & 3,22 \\
\hline & Dokter memeriksa dengan teliti & 33 & 91,7 & 3 & 91,7 & 3,08 \\
\hline & Dokter memeriksa dengan ramah & 34 & 94,4 & 2 & 5,6 & 3,08 \\
\hline & Alur pelayanan mudah & 35 & 97,2 & 1 & 2,8 & 3,11 \\
\hline & Proses pembayaran mudah, dapat melalui bank terdekat & 19 & 52,8 & 17 & 47,2 & 2,67 \\
\hline & Administrasi cepat dan mudah & 35 & 97,2 & 1 & 2,8 & 3,11 \\
\hline \multirow[t]{4}{*}{ Tarif } & Tarif sesuai fasilitas & 34 & 94,4 & 2 & 5,6 & 3,03 \\
\hline & Tarif sebanding pelayanan & 36 & 100 & 0 & 0 & 3,14 \\
\hline & Tarif rawat inap lebih mahal dibandingkan rs lain & 12 & 33,3 & 24 & 66,7 & 2,25 \\
\hline & Proses pembayaran tidak lama & 32 & 88,9 & 4 & 11,1 & 3,00 \\
\hline \multirow[t]{3}{*}{ Promosi } & Penempatan papan nama mudah terlihat & 28 & 77,8 & 8 & 22,2 & 2,78 \\
\hline & Mengetahui RSSH dari teman/saudara & 28 & 77,8 & 8 & 77,8 & 2,81 \\
\hline & Mengetahui informasi positif dari teman & 29 & 80,6 & 7 & 19,4 & 2,92 \\
\hline \multirow[t]{5}{*}{ Keahlian Karyawan } & Dokter spesialis cukup memadahi & 36 & 100 & 0 & 0 & 3,22 \\
\hline & Perawat terampil & 36 & 100 & 0 & 0 & 3,19 \\
\hline & Cleaning service cekatan & 35 & 97,2 & 1 & 2,7 & 3,14 \\
\hline & Hasil laborat cepat & 31 & 86,1 & 5 & 13,9 & 3,03 \\
\hline & Petugas memberikan informasi dengan jelas & 35 & 97,2 & 1 & 2,7 & 3,14 \\
\hline \multirow[t]{3}{*}{ Bukti fisik } & Tata ruang rawat inap menarik & 33 & 91,7 & 3 & 91,7 & 3,06 \\
\hline & Lingkungan bersih & 32 & 88,9 & 4 & 11,1 & 0,06 \\
\hline & Kantin tersedia & 29 & 80,6 & 7 & 19,4 & 2,92 \\
\hline
\end{tabular}

\section{DISKUSI}

Data responden menggambarkan pengguna RS Syuhada' Haji adalah mayoritas berjenis kelamin perempuan dewasa. Secara umum konsumen berbeda dalam hal umur, jenis kelamin, pendidikan, pekerjaan, namun juga berbeda dalam hal kegiatan, minat, pendapat dan berbagai produk yang mereka beli. Dan pemasar berusaha memahami, memenuhi, meramalkan, dan memutuskan segala kebutuhan dan keinginan konsumen (5). Kartajaya dalam Subechi berpendapat bahwa youth, women, dan netizen memegang peran strategis dalam pengambilan keputusan, termasuk disini keputusan untuk memanfaatkan rumah sakit sebagai tempat rawat inap (6). Hal ini dikuatkan oleh Wadi dan Bayu yang menyatakan bahwa semakin tinggi usia seseorang maka semakin memiliki respon yang baik terhadap produk (7).

Mayoritas pengguna rumah sakit merupakan golongan menengah kebawah, dengan tingkat ekonomi rendah namun responden mayoritas mampu membiayai pengobatan dengan biaya sendiri. Pelanggan terbesar adalah pasien baru yang datang karena rujukan keluarga. Fakta ini mengindikasikan peran strategi word of mouth dalam menjangkau konsumen dengan lebih cepat. Ardani dan Suprapti menyimpulkan bahwa word of mouth merupakan salah satu promosi yang sangat berpengaruh dalam penjualan (8).

Hasil penelitian menunjukkan penilaian pengguna pelayanan yang secara umum cenderung setuju atau positif terhadap seluruh komponen bauran pemasaran dengan penilaian tertinggi pada keahlian dan terendah pada aspek promosi. Konsumen seringkali memilih rumah sakit karena terkesan pada keahlian orang-orang yang terlibat dalam proses penyembuhannya, misalnya pada dokter spesialis yang sesuai dengan harapan, didukung dengan perawat yang terampil seringkali menjadikan pengalaman yang berkesan. Pengguna yang terkesan dengan kebaikan pelayanan rumah sakit akan merekomendasikan rumah sakit tersebut pertama kali kepada teman, ataupun keluarga bila ada yang sakit meskipun dia tidak lagi membutuhkan pelayanan kesehatan (9). Hal ini mejadi sumber referensi bagi banyak orang. Demikian sebaliknya bila pasien memberikan berkesan kurang baik terhadap dokter dan karyawan lainnya dia akan enggan memanfaatkan kembali pelayanan kesehatan tersebut dan bahkan akan menceritakan kepada teman dan keluarganya. Bauran pemasaran merupakan strategi penting organisasi untuk berhasil karena perusahaan jasa dapat bersaing dengan keunggulan yang dimiliki apabila ia mampu membangun sembilan elemen pemasaran tersebut dengan baik. Kertajaya dalam Priyanto menyebutkan kesembilan elemen tersebut adalah segmentasi, targeting, positioning, deferensiasi, marketing mix, selling, brand, service, dan proses (4).

Pada aspek promosi, salah satu item yang dinilai adalah indikator penempatan papan nama RS Syuhada' Haji apakah mudah terlihat oleh masyarakat baik di malam hari. Meskipun sebagian responden menyatakan mengetahui keberadaan rumah sakit, namun informasi papan tersebut hanya mudah terlihat dari arah Kabupaten Blitar (wilayah timur) yang ditunjukkan dengan dominasi pasar dari wilayah tersebut. Promosi mempengaruhi niat pembelian konsumen khususnya variabel periklanan (10). Persepsi pasien terhadap promosi berpengaruh positif dan signifikan kuat terhadap keputusan pasien memilih rumah sakit (11). Faktor yang mempengaruhi pengenalan masyarakat pada rumah sakit adalah informasi dan rekomendasi keluarga. Kekuatan word of mouth terletak pada kemampuannya dalam memberikan rekomendasi (12). Pengguna jasa yang merasakan manfaat dari pemanfaatan suatu produk akan cenderung 
merekomendasikan kepada orang lain diantaranya adalah keluarga (13).

Pengguna layanan rumah sakit sebagian menyatakan bahwa rumah sakit ini adalah pilihan utama, mempunyai pelayanan yang terbaik dengan proses pelayanan yang dianggap cepat. Hurrianti menyatakan bahwa proses merupakan semua aktivitas yang digunakan secara langsung oleh pengguna berupa pemanfaatan layanan kesehatan di unit rawat inap sehingga pemenuhan kebutuhan berupa pelayanan kesehatan terpenuhi sesuai dengan harapan pasien (14). Proses interaksi yang baik merupakan indikator mutu layanan jasa. Proses dalam pemasaran merupakan salah satu upaya menangkap peluang (15). Proses pelayanan memberikan pengaruh yang sangat kuat terhadap keputusan pasien dalam memanfaatkan rawat inap. Elemen proses merupakan upaya perusahaan dalam melaksanakan aktivitasnya untuk memenuhi kebutuhan dan keinginan konsumen (3).

\section{DAFTAR PUSTAKA}

1. Susanto H. Analisis Faktor-Faktor yang Mempengaruhi Bed Occupancy Rate (BOR) Rumah Sakit "Roemani" Semarang. [Tesis]. Universitas Diponegoro, Semarang. 1999.

2. Nurlia C, Hamzah A, dan Indar. Hubungan Bauran Pemasaran Dengan Keputusan Pasien Rawat Inap Memilih Layanan Kesehatan Di Rumah Sakit Islam Faisal Makassar Tahun 2011. Jurnal Administrasi dan Kebijakan Kesehatan. 2012; 1(1): 15-21.

3. Purnamasari AH, Nurhayani, Hamzah A, dan Amir Y. Hubungan Bauran Pemasaran (Marketing Mix) dengan Kunjungan Pasien di Unit Rawat Jalan RSIA Pertiwi Makassar Tahun 2011. Jurnal Administrasi dan Kebijakan Kesehatan. 2012; 1(1): 40-47.

4. Priyanto $\mathrm{SH}$, Hariyanti $\mathrm{T}$, dan Fatchurohmani. Peran Bauran Pemasaran dan Kelompok Acuan terhadap Keputusan Memilih Laboratorium Rumah Sakit AL Huda Genteng Banyuwangi. Jurnal Aplikasi Manajemen. 2012; 10(2): 450-457.

5. Schiffman L dan Kanuk LL. Perilaku Konsumen. Edisi 7. Jakarta: PT. Indeks Gramedia; 2008.

6. Subechi B. Youth, Women and Netizen Kini Pegang Peran Strategis (Online) 2014. http://www2.jawapos.com/baca/artikel/8447/yout h-women-and-netizen-kini-pegang-peran-strategis [diakses tanggal 14 Februari 2016].

7. Wadi H dan Rahanatha B. Hubungan Variabel
Keramahan petugas dinilai positif oleh responden pada penelitian ini. Pasien merasakan sikap perawat diruang rawat inap RS Syuhada' Haji selalu ramah dan tanggap terhadap keluhan pasien. Dokter di unit rawat inap melakukan pemeriksaan dengan teliti dan ramah. Hurrianti (2005) menyatakan bahwa faktor people meliputi pelaku yang memainkan peran dalam penyajian jasa sehingga dapat mempengaruhi persepsi pembeli. Semakin baik sikap karyawan (tenaga kesehatan) maka semakin mempengaruhi keputusan pasien untuk memanfaatkan rawat inap.

Kajian ini menunjukkan bahwa pengguna layanan rumah sakit mempunyai penilaian yang positif terhadap bauran pemasaran dan pelayanan rumah sakit. Rumah sakit perlu memperkuat aspek promosi dan menonjolkan kelebihan rumah sakit pada aspek keahlian dan proses pelayanan untuk meningkatkan tidak hanya penggunaan layanan tetapi juga penggunaan ulang mengingat sebagian besar pengguna adalah pengguna pertama layanan.

Demografi dengan Respon konsumen terhadap Iklan Merk Top Coffe di Kota Denpasar. Jurnal Ekonomi. 2013; 2(9): 1036-1052.

8. Ardani W dan Suprapti NWS. Pengaruh Kualitas Layanan terhadap Kepuasan dan WOM (Studi di RSUD Wangaya Denpasar). E-Jurnal Manajemen Universitas Udayana. 2012; 1(2): 240-254.

9. Kartajaya H dan Asmara B. WOW Service is Care. Jakarta: PT. Gramedia Pustaka Utama; 2014.

10. Ulfah M, Rachmi AT, dan Yuniarinto A. Pengaruh Bauran Pemasaran (Marketing Mix) terhadap Keputusan Menggunakan Jasa Rawat Jalan di Rumah Sakit Bina Sehat Jember. Jurnal Aplikasi Manajemen. 2013; 11(3): 384-391.

11. Kafa R. Pengaruh Bauran Pemasaran Jasa terhadap Keputusan Pasien dalam Memilih Jasa Rumah Sakit. Jurnal Ekonomi dan Bisnis Islam. 2013; 8(1): 105-121.

12. Basalamah FM. Pengaruh Komunitas Merek Terhadap Word of Mouth. Bisnis \& Birokrasi Journal Ilmu Administrasi dan Organisasi. 2011; 17(1)1: 79-89.

13. Rovitasari SM, Utami S, dan Sandra C. Analisis Segmentasi Pasar Pengguna Jasa Pelayanan Rawat Inap Rumah Sakit Daerah Kalisat Tahun 2013. [Repository] Universitas Jember, Jember.

14. Hurriyati R. Bauran Pemasaran dan Loyalitas Konsumen. Bandung: Alfabeta; 2005.

15. Supriyanto dan Ernawati. Pemasaran Industri Jasa Kesehatan. Edisi 1. Yogyakarta: Andi Publisher; 2011. 